\title{
Evaluation of Power Quality Issues in Grid Connected PV Systems
}

\author{
Gunjan Varshney ${ }^{1}$, D. S. Chauhan ${ }^{2}$, M. P. Dave ${ }^{3}$ \\ ${ }^{1}$ Departement of Electrical Engineering, UTU, India \\ ${ }^{2}$ Departement of Electrical Engineering, GLA University, India \\ ${ }^{3}$ Departement of Electrical Engineering, AKGEC, India
}

\section{Article Info \\ Article history: \\ Received Feb 14, 2016 \\ Revised May 23, 2016 \\ Accepted Jun 15, 2016}

\section{Keyword:}

Irradiation

MPPT

Photovoltaic

THD

UPF

\begin{abstract}
This paper presents complete simulation, modeling and control of threephase grid connected solar Photo Voltaic (PV) module including evaluation of various power quality issues. All the steps involved in complete simulation of three-phase grid connected PV module are presented and discussed in detail. Perturb and Observe (P\&O) method has been used for Maximum Power Point Tracking (MPPT). In the proposed model DC bus voltage control, harmonic mitigation and power factor control are discussed as power quality issues. The simulation results are shown in the graphical waveforms and are performed in MATLAB using SIMULINK environment and PSB toolboxes.
\end{abstract}

Copyright (c) 2016 Institute of Advanced Engineering and Science. All rights reserved.

\section{Corresponding Author:}

Gunjan Varshney,

Departement of Electrical Engineering,

Uttarakhand Technical University (UTU),

Uttarakhand 248007, India

Email: varshney.gauri@gmail.com

\section{INTRODUCTION}

Due to increased automation, now we all have become heavily dependent on electrical energy. Surely, we all have to look for the alternate sources of energy as the fossil fuels are diminishing with the time and sometimes-conventional energy sources are not capable to meet the peak load requirement. Due to limitations of fossil fuels and environmental issues, it is necessary to pay attention towards non-conventional energy sources. Many research efforts have been made and still going on in the field of non-conventional energy sources. Renewable energy source in solar form is the most imperative sustainable energy source as it is the endless source of energy.

In this paper solar PV module has been modelled using MATLAB with MPPT controller and VSC controller with constant and variable irradiation level and refrence cited therein [1]-[10]. Several investigations on MPPT methods and their comparison have been carried out with grid integration also [7][18]. In this paper, an attempt has been made to achieve MPPT using P\&O algorithm, DC bus voltage control and Unity Power Factor (UPF) at the grid side using Synchronous Reference Frame theory (SRF).

Apart from above issues, power quality also plays a very important role in grid connected PV based energy systems because power electronic based converters are to be used for MPPT and grid connection [19][23]. Due to the nature of these converters, they inject harmonics to the system and diminish the complete performance [21]-[23]. Majorly the power quality is related to the wave shape deformation or distortion. Different issues are involved in power quality such as harmonic analysis, DC link voltage regulation, power factor correction etc. [21]-[25]. The workability of the proposed model to evaluate and control the power quality issues have been confirmed by the basic models available in Simulink and SPS toolbox. 


\section{SCHEMATIC REPRESENTATION}

Figure 1 shows the basic circuit arrangement for the grid connected solar PV systems. Power electronic based DC-DC boost converter is used to step up and regulate the output DC voltage of PV module. Duty cycle (D) of boost converter is controlled with the help of MPPT control algorithm to pull out the maximum power from solar PV module. The three-phase inverter is used to convert the output DC voltage of boost converter into ac voltage and then it is connected to three-phase grid. Pulse width modulation (PWM) controller controlled by Synchronous reference frame theory has been used for the switching of IGBT based inverter [17]-[18].

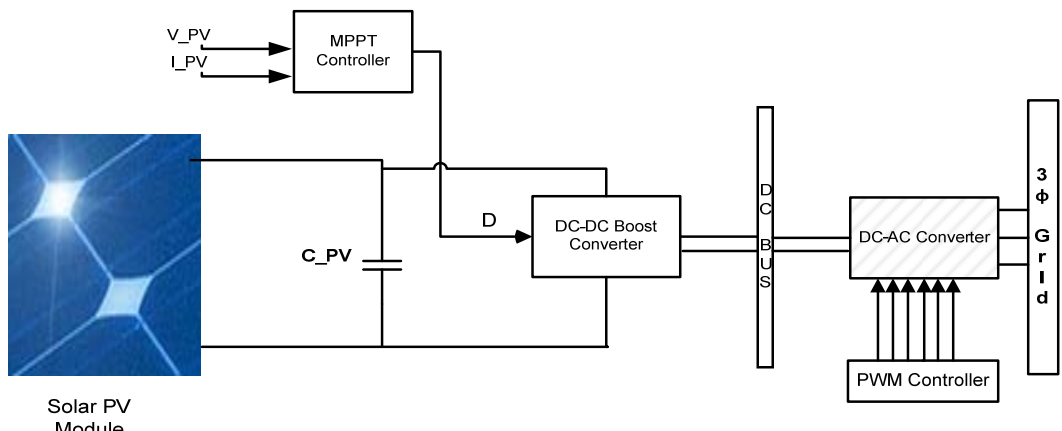

Figure 1. Schematic represntation

\section{MODELLING OF SOLAR PV CELL AND ARRAY}

The electrical equivalent model of solar cell is shown in the Figure 2 [2]-[3]. Its equations related to the I-V characteristics are expressed in the following [2],[3]:

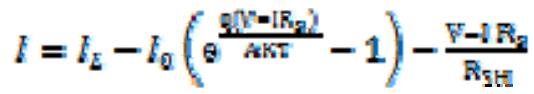

where

$\mathrm{I}=$ Solar cell output current $; \mathrm{V}=$ Solar cell output voltage $; \mathrm{I}_{0}=$ Diode saturation current,

$\mathrm{q}=$ Charge of an electron $\left(1.602 \times 10^{-19} \mathrm{C}\right) ; \mathrm{A}=$ Diode quality factor,

$\mathrm{k}=$ Boltzman constant $\left(1.381 \times 10^{-23} \mathrm{~J} / \mathrm{K}\right) ; \mathrm{T}=$ Absolute temperature $(\mathrm{K})$

$\mathrm{R}_{\mathrm{S}}=$ Series resistances of the solar cell; $\mathrm{R}_{\mathrm{SH}}=$ Shunt resistances of the solar cell

Since in the PV module, some solar cells are connected in series and some are in parallel to match the requirements of the grid. The output I-V characteristics of a PV module are given by:

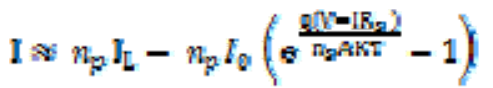

where $n_{p}$ and $n_{s}$ are the number of solar cells in parallel and series respectively [4]-[6].

Equations (1) and (2) have been modelled in MATLAB for 100KW PV array. The P-V and I-V characterstics shown in Figure 3 have been obtained using the simulink-based models. Characteristics have been presented for different levels of irradiations. All other related parameters are given in appendix-1.

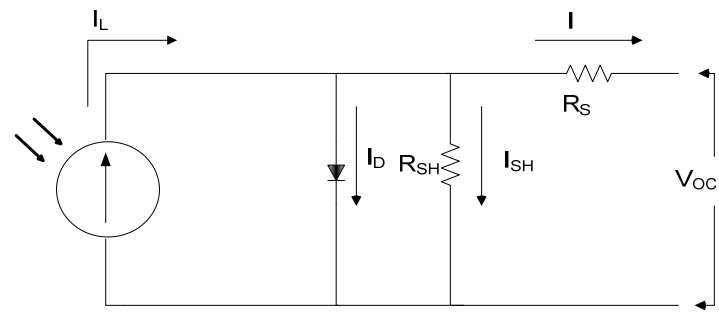

Figure 2. Equivalent circuit of PV array 

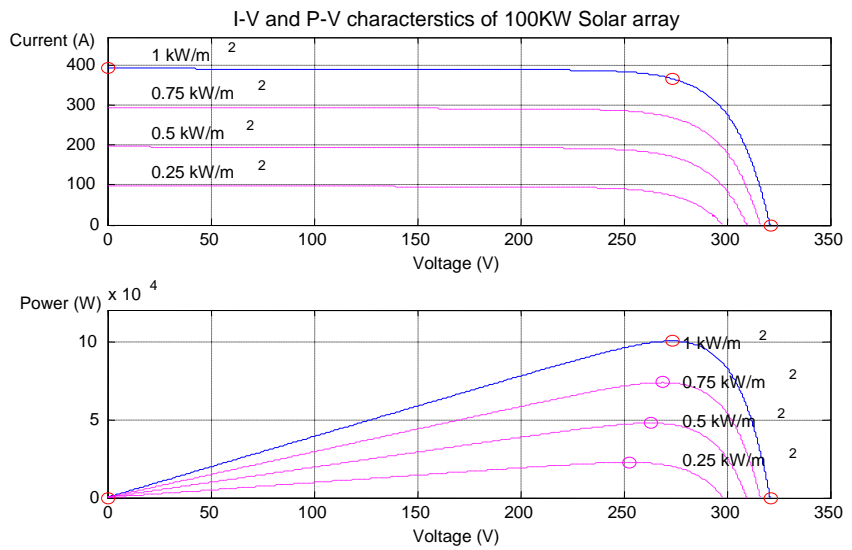

Figure 3. I-V and P-V Characteristics of 100KW solar array

\section{MAXIMUM POWER POINT TRACKING}

To obtain the maximum power from a solar module MPPT is necessary as it varies with radiation level and temperature. There are many methods available and reported in the literature to find the MPP [7][10]. Different factors are taken into consideration while applying MPP such as overall efficiency, cost, required sensors etc. In this paper Perturb and Observe algorithm is used to track the maximum power. On the basis of the flow chart of P \& O method MPPT controller is modelled in Simulink model and Duty cycle of boost converter is controlled with the help of this method [7]. The complete Simulink model of MPPT controller is shown in Figure 4.

\section{DESIGNING OF DC-DC BOOST CONVERTER}

DC-DC boost converter is used to boost and regulate the output voltage of PV module. Following equations are used for designing the boost converter [17]-[18]:

$$
\begin{aligned}
& M_{V}=\frac{E_{k}}{V_{G}}=\frac{1}{1-D} \\
& L_{\bar{L}}=\frac{(1-D)^{2} D_{N}}{2 f}
\end{aligned}
$$

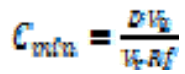

where

$\mathrm{V}_{\mathrm{i}}=$ Input voltage; $\mathrm{V}_{\mathrm{o}}=$ Output voltage; $\mathrm{D}=$ Duty cycle

$\mathrm{M}_{\mathrm{v}}=$ Gain of the boost converter; $\mathrm{C}_{\mathrm{min}}=$ Minimum capacitance required;

$\mathrm{L}_{\mathrm{b}}=$ Minimum inductance required; $\mathrm{Vr}=$ Voltage ripple

$\mathrm{R}=$ Load resistance; $\mathrm{f}=$ Switching frequency

Peak to peak ripples in output voltage is considered as $1 \%$. Parameters of the power electronic based boost converter has been calculated on the basis of designing and are used for the simulation.

\section{CONTROLLER DESIGN}

Figure 5 shows the schematic diagram for grid-connected solar system. For designing the controllers, Synchronous reference frame theory has been used [17]-[18]. It is also called dq control, used to convert control variables into DC values to achieve easy filtering and controlling. In this structure, a standard proportional-integral controller is used to regulate the DC bus voltage. The reactive power is set to be zero to achieve the unity power factor. In this paper, Phase locked loop is used to detect the phase angle of grid. The $\mathrm{d}-\mathrm{q}$ components of the currents are computed from the following equations [17]: 


$$
\left[\begin{array}{l}
i_{\alpha} \\
i_{q}
\end{array}\right]=2 \beta 3\left[\begin{array}{lll}
\sin \omega t & \sin \left(\omega t-\frac{2 \pi}{g}\right) & \sin \left(\omega t+\frac{2 \pi}{g}\right) \\
\cos \omega t & \cos \left(\omega t-\frac{2 \pi}{g}\right) & \cos \left(\omega t+\frac{2 \pi}{g}\right)
\end{array}\right]\left[\begin{array}{l}
t_{Q} \\
i_{b} \\
t_{q}
\end{array}\right]
$$

The real practicle DC voltage and reference DC voltage are compared and $I_{d} *$ is generated through a limiter using PI controller.

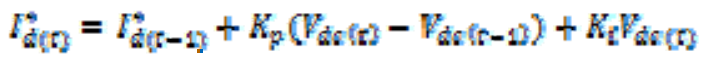

where $\mathrm{I}_{\mathrm{d}(\mathrm{t})}$ and $\mathrm{I}_{\mathrm{d}(\mathrm{t}-1)}$ are the outputs of PI controller and $\mathrm{V}_{\mathrm{dc}(\mathrm{n})}$ and $\mathrm{V}_{\mathrm{dc}(\mathrm{n}-1)}$ are the errors in DC link at $\mathrm{t}^{\text {th }}$ and $(\mathrm{t}-1)^{\text {th }}$ instants.

The d-q reference currents are converted into reference 3- -9 converter currents which are compared with the actual currents for generating the control signals for grid side converter. Here hysteresis based current controller is used to produce the gating signals of converter.

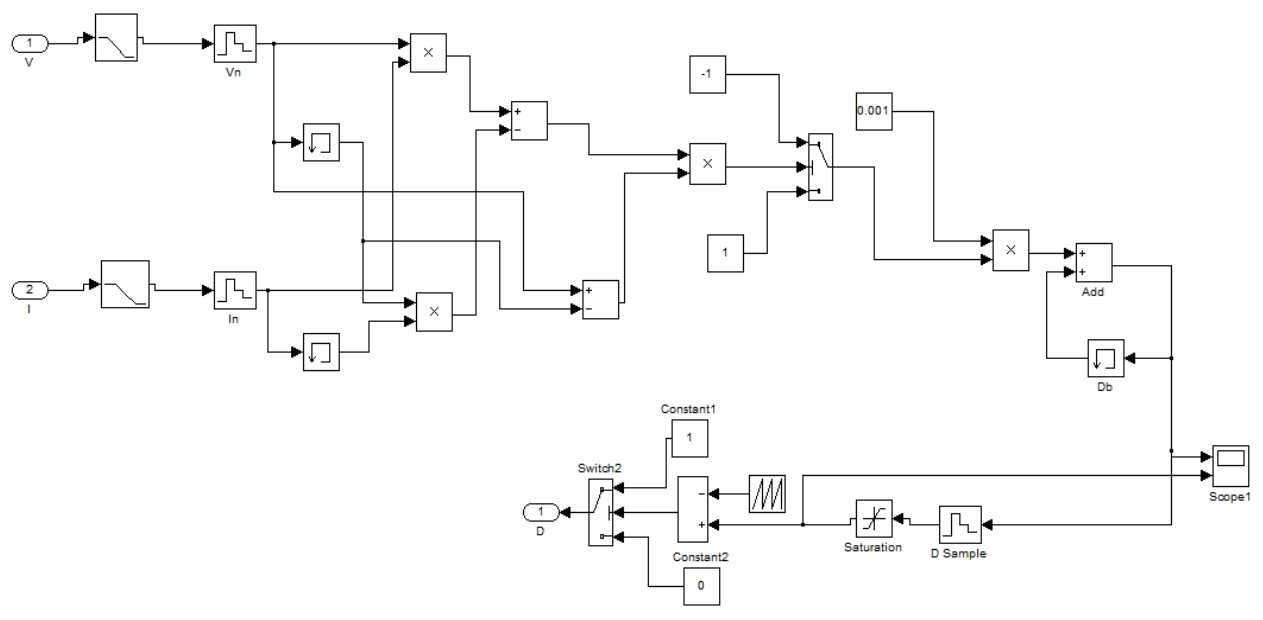

Figure 4. Matlab based model of Perturb and Observe Method

\subsection{Hysteresis Current Controller}

A possible implementation of abc control with hysteresis current control is depicted in Figure 6. PLL is used to detemine the phase angle of grid voltage. The phase reference currents are generated and are compared with the corresponding actual sensed current. The resultanant error goes into the hysteresis current controller and generates the switching signal for grid side converter.

\subsection{Power Quality Issues}

Power quality issues are related to the mainly waveform distortion. Due to the nonlinear nature of automated and power electronics, based equipment harmonics are injected into the line and cause of power quality problems such as harmonics, flicker, sag, swell, poor power factor etc. Power Quality standards are prescribed in the literatures that talk about limits of harmonics in grid voltages and grid currents [24]. In this paper, the analysis of harmonics for grid voltage, grid currents, DC voltage, and inverter output voltage before filtering and after filtering are presented as power quality issues in grid connected PV systems. Harmonics in terms of Total Harmonic Distortions (THD) in a given signal can be calculated by following formula [25]:

$$
\mathrm{THD}=\frac{\sqrt{{\sqrt{h \gamma^{2}-2}}_{h}}}{v_{1}}
$$

Where $\mathrm{h}$ is the harmonic order, $\mathrm{N}$ is the amount of samples per period and $\mathrm{N} / 2$ is maximum harmonic order. In the presented work, for calculating the THD of various signals FFT analysis tool of MATLAB is used. 


\section{RESULTS AND DISCUSSIONS}

Figure 9 shows the complete MATLAB based Simulink model of the presented grid connected PV based system. Results are shown in the form of different output waveforms.

\subsection{Outputs of DC-DC boost converters}

Figure 7(a) and (b) shows the outputs of solar array before boost converter and after boost converter. It is very clear from the waveforms, before boost converter the DC output voltage of solar array is within the range of 250-300 volts and after boost converter the DC voltage is boosted up to 500 volts. Duty cycle of the IGBT based DC-DC boost converter is controlled through MPPT algorithm.

\subsection{Output of MPPT controller}

Figure 8 shows the output of MPPT controller in terms of Duty cycle. Duty cycle is shown for constant and variable irradiation both.

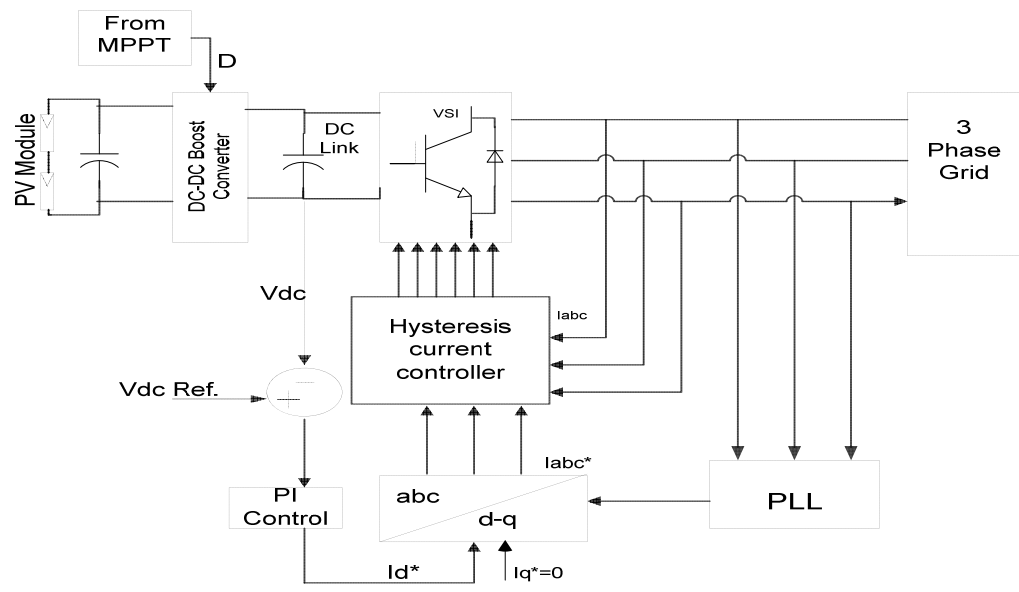

Figure 5. VSC Controller

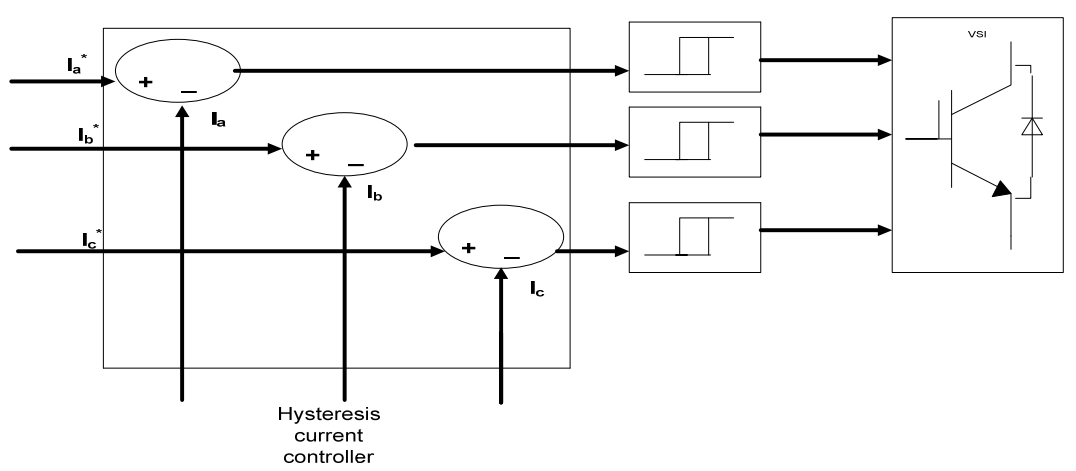

Figure 6. Block diagram for Hysteresis Current Controller

\subsection{Evaluation of Power Quality Issues}

Figure 10 shows the performance of grid-connected solar system for constant irradiation. The waveform shows the grid voltages, grid currents, solar irradiations, and DC bus voltage, active power respectively. In this figure, results are shown for constant irradiations $\left(1000 \mathrm{~W} / \mathrm{m}^{2}\right)$. DC bus voltage is maintained constant at 500V. Power factor is achieved unity as grid voltages and grid currents are in phase.

Figure 11 shows the performance of the grid-connected solar system with variable irradiation level. Under the variable irradiation level VSC controller is able to control the DC bus voltage and power factor at all solar radiations.

Figure 12 shows the harmonic analysis of grid side voltage that is the major part of the power quality. Total harmonic distortion (THD) is calculated using FFT analysis tool of MATLAB [24]-[25]. The 
\%THD is calculated for grid voltage, grid currents, inverter voltage before filtering and after filtering and DC link voltage and shown in the Table-1. Harmonics in all the signals are satisfying the IEEE limits [24].

Table 1.

\begin{tabular}{|c|c|}
\hline $\begin{array}{l}\begin{array}{l}\text { Signals of the grid connected PV system for which THD } \\
\text { has been calculated }\end{array} \\
\text { ? }\end{array}$ & $\begin{array}{l}\text { Power Quality evaluation } \\
\text { in terms of THD }\end{array}$ \\
\hline Grid voltage & $0.04 \%$ \\
\hline Grid current & $0.32 \%$ \\
\hline Inverter voltage before filter & $36.3 \%$ \\
\hline Inverter voltage after filter & $2 \%$ \\
\hline DC bus voltage( w.r.t to DC fundamental value) & $0.04 \%$ \\
\hline
\end{tabular}

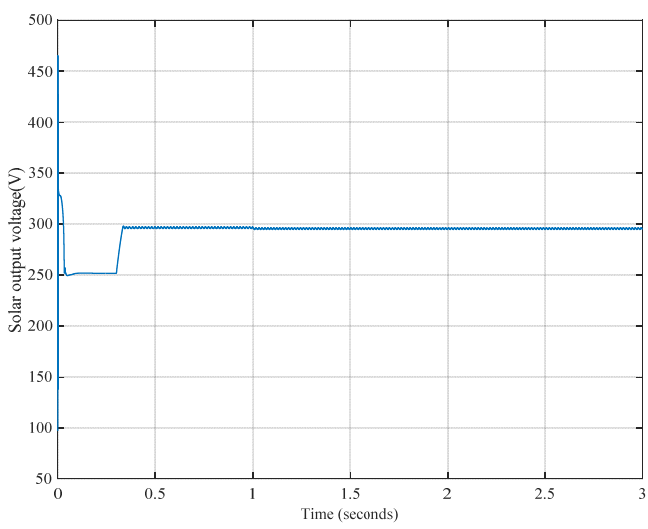

(a)

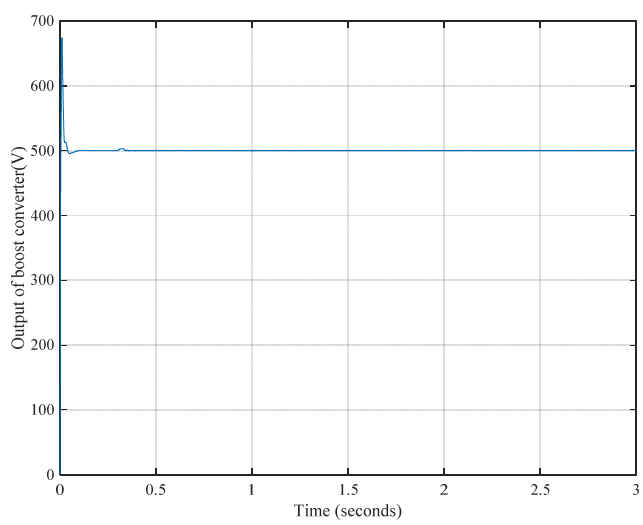

(b)

Figure 7. (a) and (b) Input and output voltage of Boost converter

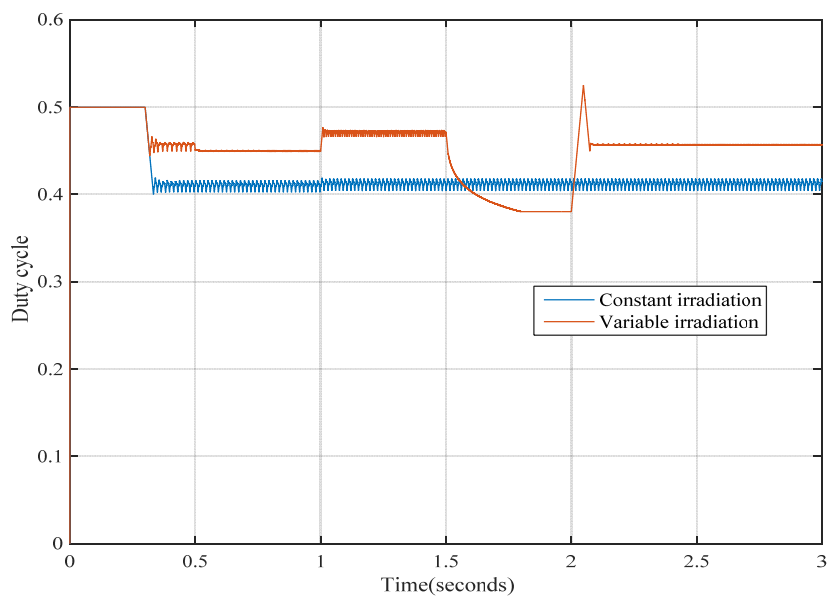

Figure 8. Duty cycle 


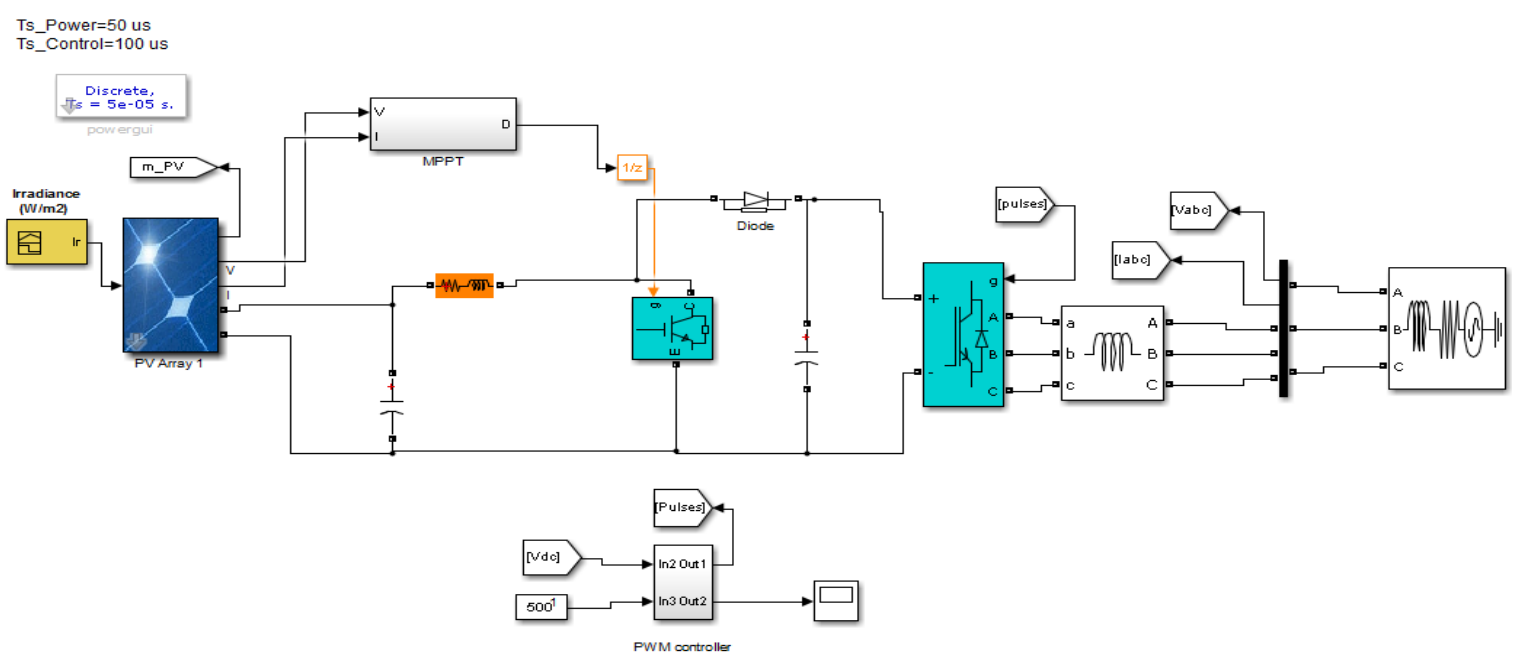

Figure 9. Complete simulink model of grid connected PV array
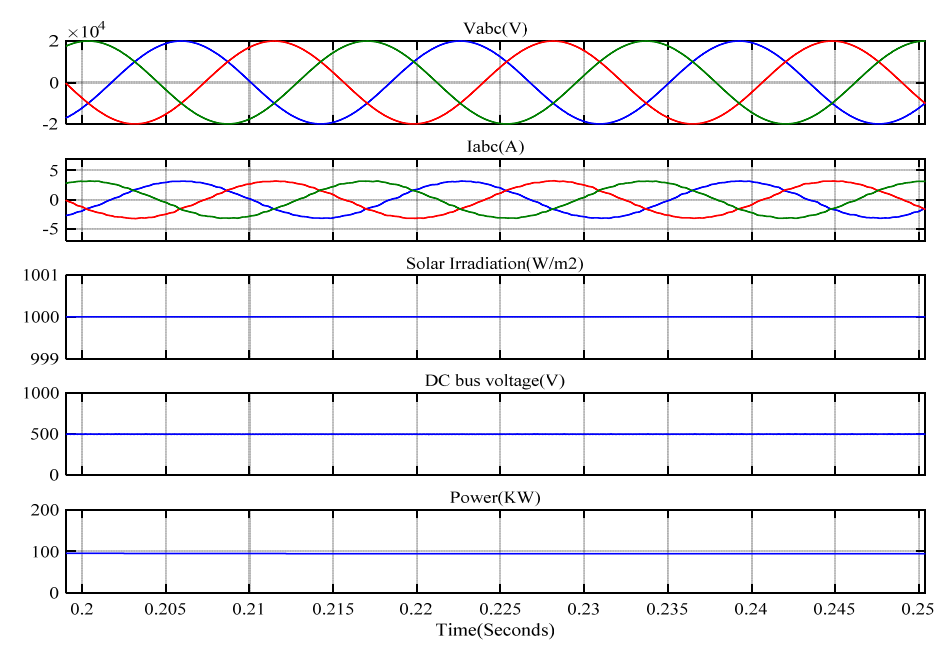

Figure 10. Performance analysis with constant irradiation
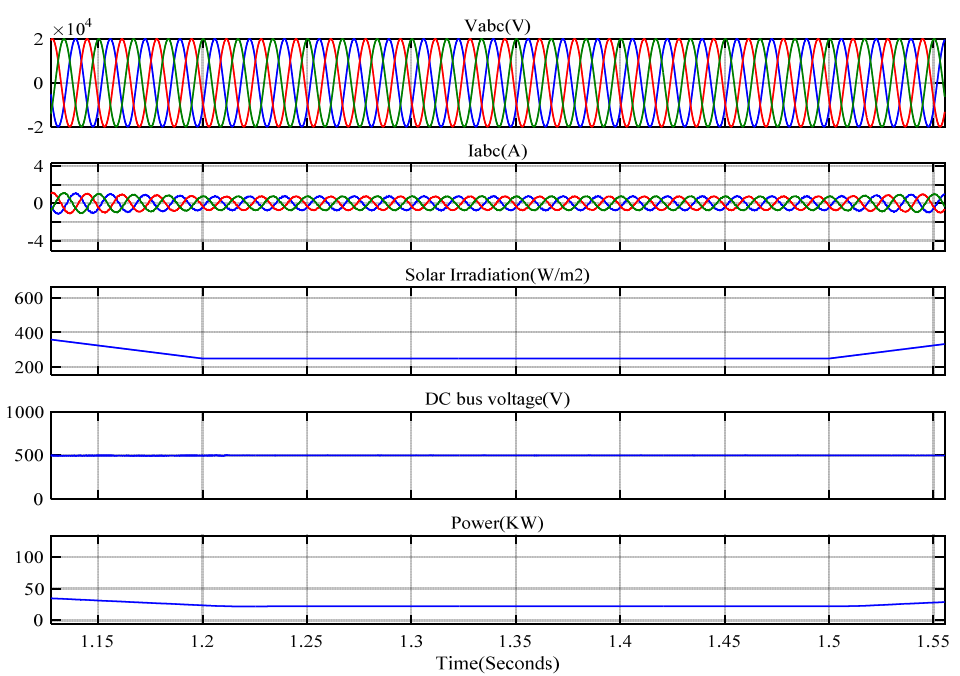

Figure 11. Performance analysis with variable irradiation 

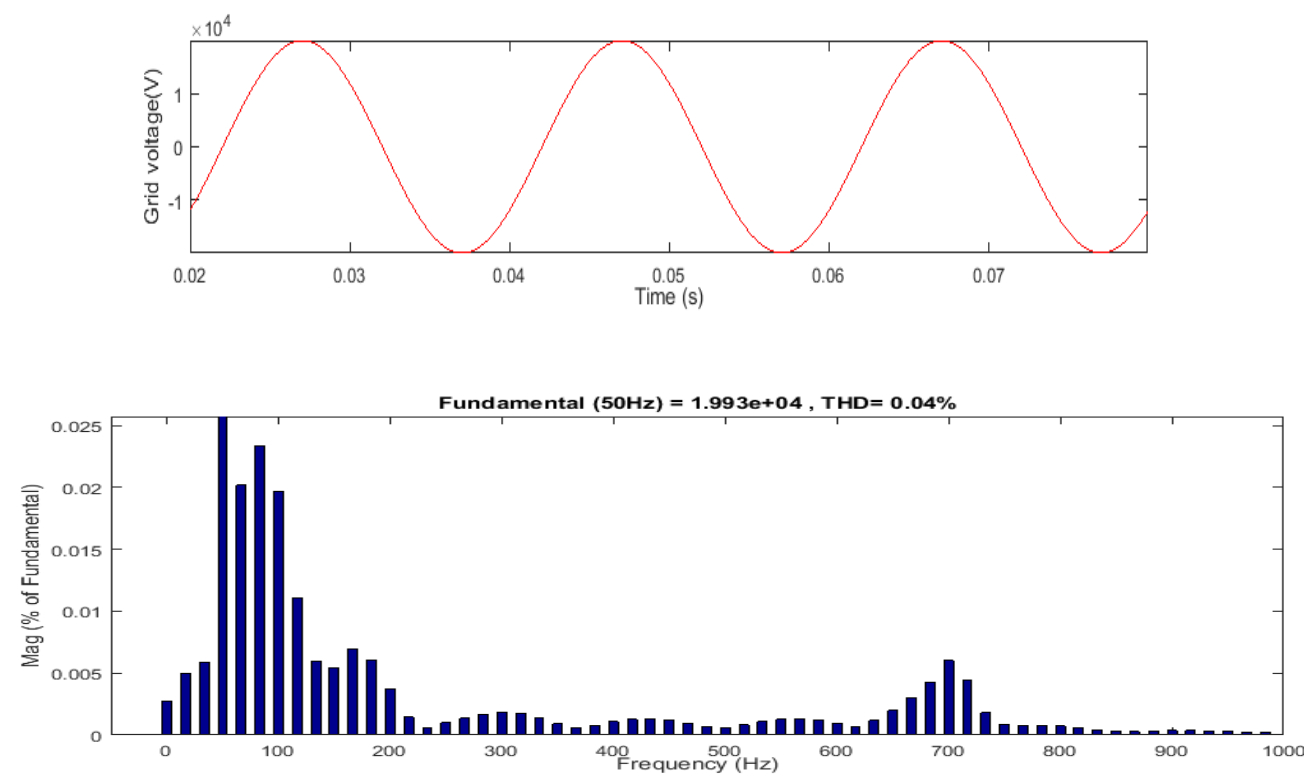

Figure 12. Waveform and harmonic spectrum of grid voltage

\section{CONCLUSION}

This paper provides a complete overview for the analysis of power quality related issues along with the modelling and control of grid connected photovoltaic system. Synchronous reference frame theory based controller has been used to control the grid side Power Factor. The results are obtained using MATLAB software and in Simulink environment for constant and variable irradiation and also in terms of DC link voltage regulation, Power factor and harmonic analysis. \%THD has been calculated for grid side voltage, current, inverter voltage and DC link voltage and presented in bar forms.

\begin{tabular}{ll}
\multicolumn{2}{c}{ Appendix-1. System Parameters } \\
\hline Solar PV Module & Sun Power SPR -305-WHT \\
Solar PV specifications & $100 \mathrm{~kW}$ \\
No. of cells per module & 96 \\
No. of series connected modules per string & 5 \\
No. of parallel connected strings & 66 \\
V $_{\mathrm{OC}}$ of the PV module & $64.2 \mathrm{Volt}$ \\
$\mathrm{I}_{\mathrm{sc}}$ of the PV module & $5.96 \mathrm{Amp}$. \\
$\mathrm{V}_{\mathrm{mp}}$ of the PV module & 54.7 \\
$\mathrm{I}_{\mathrm{mp}}$ of the PV module & 5.58 \\
Switching Frequency of VSI & $10 \mathrm{kHz}$ \\
DC bus voltage & $500 \mathrm{Volt}$ \\
\hline
\end{tabular}

\section{REFERENCES}

[1] M. Arunbhaskar, et al., “A Simple PV Array modelling using MATLAB,” Proc. ICETECT, 2011.

[2] J. S. Kumari and C. S. Babu, "Mathematical modeling and simulation of photovoltaic cell using Matlab-Simulink environment,” International Journal of Electrical and Computer Engineering, vol/issue: 2(1), pp. 26, 2012.

[3] T. Salmi, et al., "MATLAB/Simulink Based Modelling of Solar Photovoltaic Cell," International Journal of Renewable Energy Research, vol/issue: 2(2), 2012.

[4] S. R. Nandurkar, et al., "Modeling Simulation \& Design of Photovoltaic Array with MPPT Control Techniques," International journal of applied power engineering, vol/issue: 3(1), pp. 41-50, 2014.

[5] R. Krishan, "The simulation and design for analysis of photovoltaic system based on MATLAB," ICEETS, Nagarcoil, 2013.

[6] F. M. González-Longatt, "Model of photovoltaic module in Matlab. In 2do congreso iberoamericano de estudiantes de ingenierıcute,” aeléctrica, electrónica y computación, ii cibelec, pp. 1-5, 2005.

[7] T. Esram and P. L. Chapman, "Comparison of Photovoltaic Array Maximum Power Point Tracking Technologies," IEEE Trans. on Energy Conv., vol/issue: 22(2), pp. 439-449, 2007.

[8] N. T. Abraham, et al., "Literature Survey of SAR Algorithm in Photovoltaic System," International Journal of Electrical and Computer Engineering, vol/issue: 4(2), pp. 155, 2014.

[9] F. Liu and Y. Kang, "Comparison of P\&O and hill climbing MPPT methods for grid-connected PV converter," 
Industrial Electronics and Applications, 2008.

[10] V. Salas, et al., "Review of the maximum power point tracking algorithms for stand-alone photovoltaic systems," in Sol. Energy Mater. Sol. Cells, vol/issue: 90(11), pp. 1555-1578, 2006.

[11] Z. Dejia and E. Tal, "Design and Control of Three phase grid connected Photovoltaic System with developed Maximum Power point tracking," APEC, Austin, TX, 2008.

[12] B. A. Abdallah and L. Djamel, "Control of power and voltage of solar grid connected," International Journal of Electrical and Computer Engineering (IJECE), vol/issue: 6(1), 2015.

[13] S. N. Nikolovski, et al., "Integration of Solar Power Plant in Distribution Network," International Journal of Electrical and Computer Engineering, vol/issue: 5(4), pp. 656, 2015.

[14] E. Twining and D. G. Holmes, "Grid current regulation of a three-phase voltage source inverter with an LCL input filter,” IEEE Trans. Power Electron, vol/issue: 18(3), pp. 888.895, 2002.

[15] M. Liang and T. Q. Zheng, "Synchronous PI Control for three-phase grid connected Photovoltaic Inverter," Chinese Control and Design Conf., 2010.

[16] D. M. Brod and D. W. Novotny, "Current control of VSI-PWM inverters,” IEEE Trans. Ind. Appl., vol/issue: 21(4), pp. 562-570, 1995.

[17] B. Singh, et al., "A new control approach to three phase active filter for harmonics and reactive power compensation," IEEE trans. Power system, vol/issue: 13(1), pp. 133-138, 1998.

[18] M. M. Amin, et al., "DC bus voltage control for PV sources in a DC Distribution System Infrastructure," Power and Energy society general Meeting, Minneapolis, MN, 25-29 july-2010.

[19] R. N. Tripathi and A. Singh, "SRF theory based grid interconnected Solar Photovoltaic (SPV) system with improved power quality,” International IEEE Conference on Emerging Trends in Communication, Control, Signal Processing \& Computing Applications (C2SPCA), Banglore, India, 2013.

[20] R. Garg, et al., "Direct Current Control of Grid connected Photovoltaic Distributed Generation system," AIJRSTEM, pp. 123-127, Sep-Nov 2013.

[21] Ghosh and G. Ledwich, "Power Quality Enhancement Using Custom Power Devices,” Kluwar academic publishers, London, 2002.

[22] D.C. Dugan, “Electrical Power Systems Quality, 2edition,” McGraw Hills, New York, 2006.

[23] K. K. Weng, et al., "Power Quality Analysis for PV Grid Connected System Using PSCAD/EMTDC," International Journal of Renewable Energy Research, vol/issue: 5(1), 2015.

[24] IEEE, "Guide for harmonic control and reactive compensation of static power converters," IEEE standard 519, 1992.

[25] G. E. Mog and E. P. Ribeiro, "Total harmonic distortion calculation by filtering for power quality monitoring," Transmission and Distribution Conference and Exposition: Latin America, 2004 IEEE/PES, IEEE, 2004.

\section{BIOGRAPHIES OF AUTHORS}

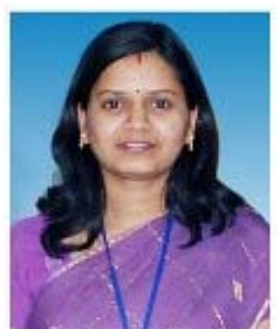

Gunjan Varshney received her B.E. degree from RTU, India in 2004 and M.Tech.degree from UPTU,India in 2012. Currently she is research scholar in UTU, India. Her research areas are Power Qualityand its Improvement, Renewable energy sources and Power systems.

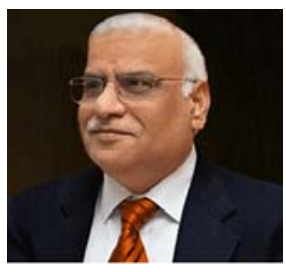

Prof. D S Chauhan has obtained his B.Sc. Engg. (Electrical) from IIT Banaras Hindu University (BHU), M.Engg. (Power System) from Madras University, TN and Ph. D. from IIT Delhi, New Delhi. He has done his Postdoctoral Research from NASA, USA. He had been the Professor in IIT-BHU Varanasi. His research areas are power system, renewable energy resources and power quality.

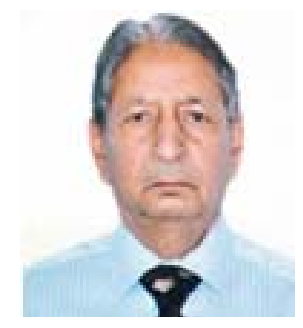

Prof. M P Dave is currently working as Professor Emeritus in AKGEC, Ghaziabad; India.He has obtained his M.Tech from IISC banglore in1965, Ph.d. from University of Roorkee in 1969 and Dr-ING in 1972 from west germany. His research areas are Power System, On line Control, Control System and Renewable Energy. 